\title{
A NEW PARADISE.
}

By HaROLd B. SHINN, Schure High School, Chicago.

The dune region on the south shore of Lake Michigan has of late years become a famous rendezvous for biologist and geographer, and even should it fail to be saved from encroaching industrial enterprise, it will have served a good ..purposethat of awakening a wide public interest in nature. It has been written about in many journals and has even furnished a livelihood to the lecturer, though we are not aware that it has yet produced a literature similar to that of the "Limberlost." But farther down the lake, away from the smoky pall of a great city and the shriek of nearby train, and unsullied by sardine tins and dirty paper napkins, lies a paradise as yet unknown and unexplored save by a very few. This spot should be visited at least once by every nature lover.

Ludington lies on the east shore of Lake michigan, easily accessible by railway from within the state or by steamboat direct from Chicago and from Milwaukce. The auto route connecting the shore cities of Michigan passes through it "on high." To the tourist who reads the older story there is pleasure in deciphering the glacial history, the advancings and retreatings of the ice sheet, the situations of large lakes and watercourses, and the piling up of moraines until they imitate very strikingly the Jurassic Alps. The locality abounds in small lakes and streams replete with fish, from trout to muskelunge, with bass and pickerel always numerous. Game birds, too, there are, and the shore line migration route makes possible bird studies hardly to be duplicated in the central states.

Society in summer hugs the town, boating, motoring, professional baseball, golf, and a chautauqua amusing a few thousand tourists and resorters. But six miles north begins a wonderful wilderness, a hundred square miles in extent. Here is our "Paradise." Beginning at the west, one finds the xerophytes of wide beaches and high dunes. Eastward for many miles are alternating hills, with dead lakes and lagoons between them, and broad moors of sphagnum, eranberry and huckleberry. A part of the government reservation, near the Great Point Sauble light, is a large tract of primitive timber to be penctrated only with a compass at hand, and here still lurk the deer and bear. Cranberry, huckleberry of several varieties, and the wintergreen are yearly harvested, each in its season, by Indians and venturesome whites. 
The forester revels in the varicty of the woods. Like the glacial soil, a heterogeneous mass of many materials, so the trees seem thrown together by a lavish hand; beech, ash, birches too, oaks, maples, cherry, hemlocks, spruces, tamarack, pines and cedars challenge him. The ecologist is at a loss where to begin his work. Indian pipe, ginseng, sundew, orchids, pitcher plant, and lichens are without number. Ant lions pit the dune sides; spiders of many habits burrow or build their homes and snares; the gulls and snowy geese and a lone bald eagle sail between the crystal sky and the great emerald lake while from hill to hill sounds the flute of the cardinal.

The southern boundary of this paradise is Hamlin Lake and its heading stream, Sauble River. These waters furnish pleasure enough and excitement enough for the most cxacting throughout the year. It matters little whether the student enters the domain at one season or another. In spring the trout are taking the fly, the partridge are drumming, and the arbutus bedecks the hillside, throwing its delicate scent to the winds, while in shady woods trilliums and Canada violets, phlox and Dutchmen's breeches, carpet the ground. In midsummer the lake is "in bloom" with plankton, insect life is at its height, while chewink and warbling vireo lure you farther into the thickets. In fall the squirrel and chipmunk are busy with nut and seed, the hunter is bagging his stock to be frozen for use until spring comes again, and in the foliage nature is breaking down her greens through the series of catalyses to reds, yellows, and browns. Snowshoe and ski, in winter, carry you over the trail with camera or gun or trap for fox, muskrat, or skunk, or maybe you fish for "muskies" through the ice.

Words are inadequate to describe this rendezvous so easily accessible to nature lovers of the central states, and ScHOoL Science And Mathematics has asked one of the permanent residents, formerly a city dweller, to describe certain phases of the life as she knows it.

Winter at Hamlin Lake.

Dec. 1, 1920.

"Every day I find something interesting, and wish I could spend all my time wandering through the woods and marshes, to see how the plants, as well as the little animals, have provided for the winter; and still hardly a day passes that I don't receive a letter saying, 'How do you spend your time? I should think you would die of lonesomeness out there in the woods!' My dear 
friends, what is lonesomeness? How can one be lonesome with all the beautiful and interesting things God has given us to enjoy in this wonderfully beautiful country?

"The weather so far has been very mild and most of the leaves are still on the trees, and I still find the little wild aster in bloom, where it has been sheltered a bit, and now and then a bluebell and many strawberry plants are blossoming. I have never seen the wintergreen plant so loaded with berries; it is a pretty sight, the patches of green and red wherever you go. The trees are also loaded with the winter fruit, the cedar trees so loaded with sced and fruit, the hemlock and spruce with many little cones. A few weeks ago I took a party of friends to the bluff; to gather bitter-sweet and by the time we reached there, they all had their baskets filled with interesting things, among them the wonderful trailing arbutus in bloom, for the weather was so nice it just could not wait until spring.

"Thanksgiving morning seemed like spring, for as I went out to feed the chickens, a flock of robins greeted me with their 'cheerily -cheer-up' and the little chickadees tried to tell me how happy and contented they are here. We have the little song sparrow and the creepers, nut hatch and junco in great flocks. The little chipmunks and red squirrels have been very busy this fall, for where they had to live mostly on acorns for the last few winters, they now have had all the beechnuts they want to store away; in one hollow stump where I knew a chipmunk lived, I found at least three quarts of becchnuts and acorns.

"We have a great many partridge this year, for the weather was very favorable during hatehing time, for baby partridge cannot stand wct weather and when we have a cold wet spring, many of the little ones die. This is ideal weather for them, too, for they have lots to eat, as they like the wintergreen berries and beechnuts and they are well protected from the hunter as well as the owl on account of the heavy foliage on the trees and shrubbery. Every time I go for a walk through the woods I see them, in pairs mostly, but very often in flocks of six to eight, and usually when I have my basket instead of the gun.

"Hamlin Lake has always been a place where the wild duck come in great flocks, and from the time the season for hunting opens, we have duck of many species and we spend early mornings and late afternoons in hunting.

"Last winter at this time we had the suet baskets and feeding boxes filled for the little birds, for we had lots of snow and 
very cold weather and the little friends had hard work finding food until they came to us; but this ycar it is so mild and there is so much for them to eat I have decided not to feed them until the snow covers the ground, for fear it will make them lazy and they might suffer later on when it gots really cold. We have one hundred and twenty bird houses on our premises and thirty suct baskets. We also have fifteen feeding boxes and in cold weather I bake bread for the birds and put it in the feeding boxes. I mix corn meal, oat meal, bran and a little wheat flour, with enough water to make a stiff dough, and add a little molasses and soda, which makes very good food for them, and if you could see them at the feeding boxes you would not have to ask, 'Do they like it?'

\section{GOD's COUN'rry.}

"While you're living in the city, with its fashion and its strife, I think, dear friends, you are missing part of life-

For here in God's own country, we're as happy as can be, Don't have to copy fashions, and every day we sce

Something new and interesting. I assure you there is charm In what God gave us to care for, to enjoy and keep from harm. There is no thought of envy, no need to sit and think, 'Which gown would look the best on me, shall it be blue, or pink?'

For our friends are not ashamed of us, no matter what we wear, And when they sec us coming, we are sure to find them there, Waiting patiently to greet us. They never ask the recipes Of the things we set before them, we just know that they are pleased

By the way they twit and twitter, as they ny from tree to tree. Eating suet and the meal cakes, they arc happy as can be." -["Mary A. Nurnberg."

FILM ILLUSTRATING PLANE GEOMETRY.

Mr. Charles H. Sampson of the Massachusetts Department of Education is now at work preparing a film on the subject "Defimitions of Plane (ieometry."

This is something unique in educational matters. A portion of this film was recently shown at a teachers' convention in Boston and ereated a great deal of favorablo comment. 'The completed film will soon be shown to the publie, after which it will be ready for distribution.

This, undoubtedly, is the first time that anything of this kind has been attempted in this direction. Mathomaties teachecs should get in touch with Mr. Sampson concerning the mattor. 